\title{
Turf Performance of Bahiagrass, Centipedegrass, and St. Augustinegrass Cultivars under a Linear Gradient Irrigation System
}

\author{
Jing Zhang and J. Bryan Unruh ${ }^{1}$ \\ Department of Environmental Horticulture, University of Florida, West \\ Florida Research and Education Center, 4253 Experiment Road, Highway \\ 182, Jay, FL 32565

\section{Kevin Kenworthy \\ Department of Agronomy, University of Florida, 3105 McCarty Hall B, Gainesville, FL 32611}

Additional index words. warm-season turfgrass, drought response, visual rating, chlorophyll index

\begin{abstract}
Periodic drought, irrigation requirements, and the enforcement of mandatory watering restrictions have posed a challenge for homeowners and landscape managers to maintain acceptable turf quality during dry periods. Information regarding irrigation requirements and performance of common turfgrass species used for residential and commercial landscapes in the southeastern United States would be valuable. A Linear Gradient Irrigation System (LGIS) provides an efficient way to measure cultivar responses to variable moisture regimes. Nine commercially available cultivars from three turfgrass species: 'Argentine' bahiagrass (BH) (Paspalum notatum Flügge); 'Common' and 'TifBlair' centipedegrass (CP) [Eremochloa ophiruoides (Munro) Hack.]; 'Captiva', 'Classic', 'Floratam', 'Palmetto', 'Raleigh', and 'Sapphire' st. augustinegrass (STA) [Stenotaphrum secundatum (Walt.) Kuntze.] were evaluated during naturally occurring dry periods in 2010 and 2011 for visual quality, color, and density and chlorophyll index. An irrigation gradient ranging from $0 \%$ to $120 \%$ of reference evapotranspiration (ET $_{0}$ ) was provided by LGIS. Centipedegrass and BH had less demands on supplemental irrigation to maintain acceptable quality during periodic drought compared with STA. 'Argentine' BH performed similar to 'Common' CP for its visual quality except at the irrigation level of $40 \%$ ET $_{0}$. Among STA cultivars, 'Palmetto' performed poorest in its relative drought response than other cultivars. 'Sapphire' STA needs further study to better characterize its drought response. The irrigation level of $120 \%$ ET $_{0}$ decreased turf quality except for 'Argentine' $\mathrm{BH}$, and the irrigation replacement at $40 \%$ to $80 \% \mathrm{ET}_{\mathrm{o}}$, depending on turfgrass species and cultivar, may provide enough supplemental moisture to maintain acceptable turf quality during shortduration drought $(\approx 2$ weeks) in north Florida regions.
\end{abstract}

Bahiagrass, $\mathrm{CP}$, and STA are widely used turfgrass species for home lawns and landscapes in the southeast United States (Trenholm et al., 2011a, 2011b; Unruh et al., 2011). In Florida, these three species accounted for $87 \%$ of sod production acreage in 2007 (Satterthwaite et al., 2009). However, periodic drought, the irrigation requirements of these managed areas, and mandatory watering restrictions have posed an inevitable challenge for homeowners and landscape managers. Understanding the differences in relative water requirements and drought performance of different turfgrass species and cultivars will help the end-users (homeowners, sod producers, property managers,

Received for publication 11 Sept. 2014. Accepted for publication 6 Jan. 2015

${ }^{1}$ To whom reprint requests should be addressed; e-mail jbu@ufl.edu. etc.) to maximize the use of water resources in their future practices.

The comparative water consumption of these three species under non-limiting moisture conditions has been documented in a few studies. Centipedegrass was found to have a lower evapotranspiration (ET) rate $\left(5.5 \mathrm{~mm} \cdot \mathrm{d}^{-1}\right)$ compared with 'Argentine' BH (6.3 mm. $\left.\mathrm{d}^{-1}\right)$ and 'Texas Common' STA $\left(6.3 \mathrm{~mm} \cdot \mathrm{d}^{-1}\right)$ (Kim and Beard, 1988). In another greenhouse study, 'Argentine' BH was found to use $30 \%$ more water on a daily basis than 'Floratam' STA under well-watered conditions (Cathey et al., 2013).

The performance of different turfgrass species and cultivars during water deficit or drought conditions has been published (Carrow, 1996; Huang et al., 1997a, 1997b; Qian and Engelke, 1999; Steinke et al., 2010). Results of the previous studies regarding existing variations among species and cultivars suggest that irrigation can be reduced based on choosing the right species and cultivars for the local environment. However, information is lacking on water use and drought performance of these commercially available cultivars under similar maintenance levels, growing in the subtropical climate on sandy soils found in North Florida. St. augustinegrass dominates the residential and commercial landscape market in Florida with $51 \%$ of total sod production (Satterthwaite et al., 2009). In a study comparing seven STA cultivars during a 60-d drought in San Antonio, TX (Steinke et al., 2010), up to a 15-d difference was identified among cultivars in losing 50\% green cover, and 'Floratam' provided the most consistent drought performance over 2 years. In addition, the drought response of 'TifBlair' and 'Common' CP has never been compared in the same study, only in separate studies (Carrow, 1995; Huang et al., 1997a) with other species.

A LGIS produces a uniform irrigation gradient and is a desirable system used to evaluate the drought responses of turfgrasses. Several studies have been conducted with LGIS to determine minimum irrigation requirements and to evaluate the persistence of turfgrasses under various irrigation regimes (Bañuelos et al., 2011; Qian and Engelke, 1999; Zhang et al., 2013). The objective of this study was to evaluate the performance of nine commercially available turfgrass cultivars commonly grown in home lawns and commercial landscapes of the southeastern United States during naturally occurring dry periods using a LGIS.

\section{Materials and Methods}

Site construction. The LGIS was constructed at the University of Florida, West Florida Research and Education Center (WFREC), Jay, FL, in 2008. The soil is an Orangeburg sandy loam (fine-loamy, kaolinitic, thermic Typic Kandiudults) with $\mathrm{pH} 5.5$ and $1 \%$ organic matter. The LGIS system was modeled after Texas AgriLife Research and Extension Center, Dallas, TX (Qian and Engelke, 1999). The system was lasergraded to have a $12.7-\mathrm{cm}$ drop from both outside perimeters toward the center line. The LGIS center line was oriented parallel to the prevailing winds and was laser-graded with a $0 \%$ slope along that axis. The irrigation system along the central line has a row of sprinkler heads (Rain Bird ${ }^{\circledR}$ EAGLE $^{\text {TM }} 900$ heads fitted with nozzles, Azusa, CA) spaced at $33 \%$ of the maximum throw of each head $(8.13 \mathrm{~m})$ to provide a perpendicular irrigation gradient from the irrigation source (center) to the outside (Fig. 1). An additional row of sprinkler heads was placed along each outside edge (24.38-m spacing). The outside irrigation rows were only used during establishment and for watering in fertilizer.

Plots establishment and maintenance. Nine turfgrass cultivars were planted as sod into $3.1 \mathrm{~m} \times 24.4-\mathrm{m}$ plots aligned perpendicular to the center line of the irrigation heads in Sept. 2008 (extending $24.4 \mathrm{~m}$ from the center line). Cultivars planted included: 'Argentine' BH; 'Captiva', 'Classic', 'Floratam', 'Palmetto', 'Raleigh', and 'Sapphire' STA; and 'Common' and 'TifBlair' CP. The study 


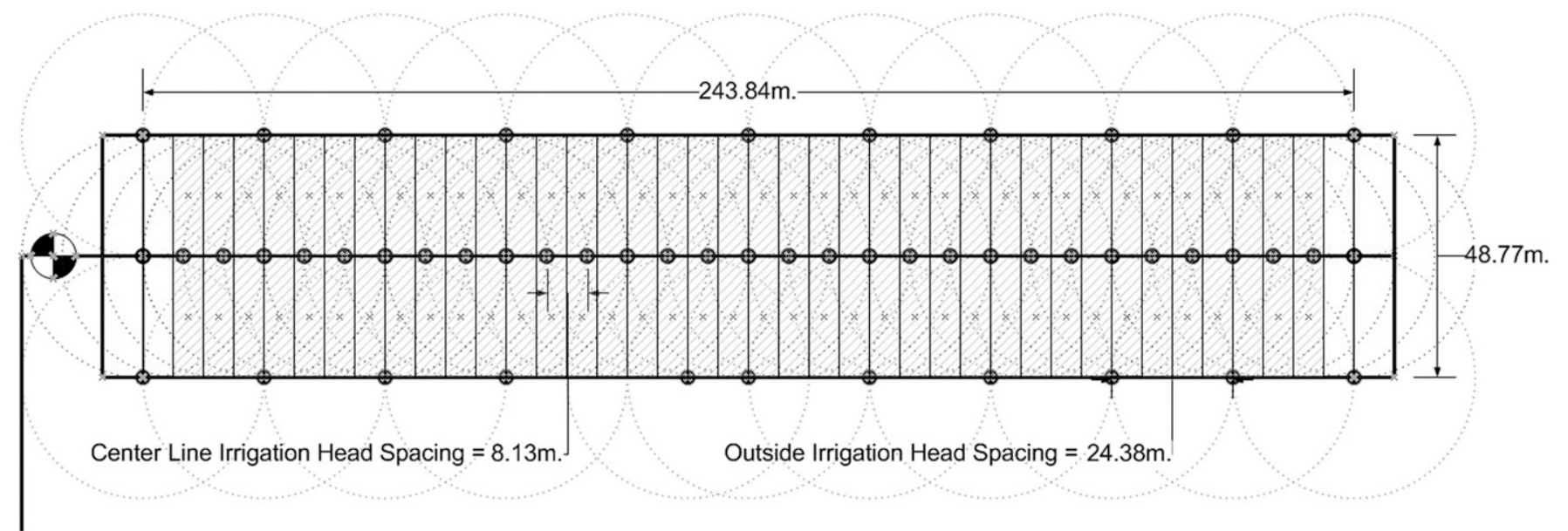

Fig. 1. Diagram of the Linear Gradient Irrigation System (LGIS) showing the positions of the irrigation sprinkler heads in the central line and the outside edge. One strip in the diagram, which is aligned perpendicular to the central irrigation line, is the size of two plots.
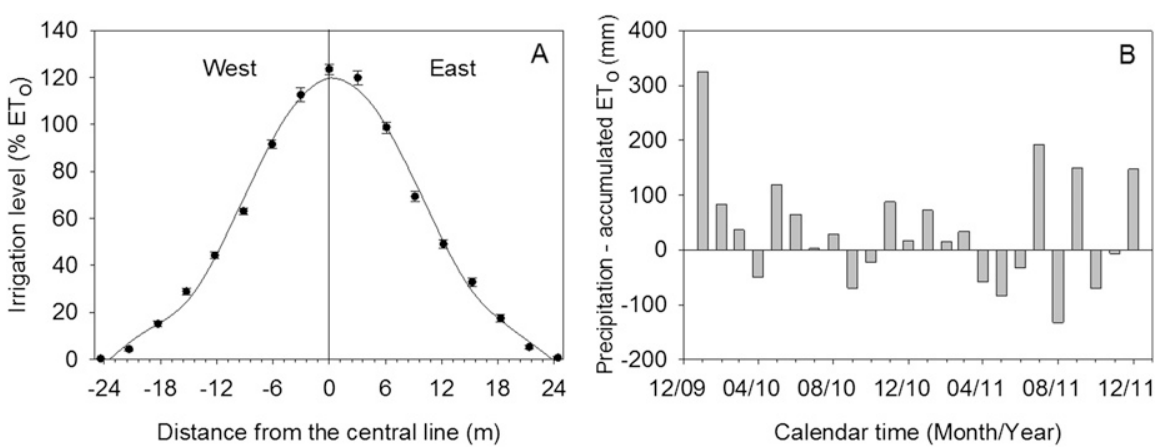

Fig. 2. (A) Irrigation distribution of the Linear Gradient Irrigation System (LGIS). Fitted equation: $\% \mathrm{ET}_{\mathrm{o}}=$ $119.88+0.58 \mathrm{X}-0.69 \mathrm{X}^{2}-2.4 \mathrm{E}-3 \mathrm{X}^{3}+1.5 \mathrm{E}-3 \mathrm{X}^{4}+2.46 \mathrm{E}-6 \mathrm{X}^{5}-1.15 \mathrm{E}-6 \mathrm{X}^{6} \cdot R^{2}=0.90$. The vertical bars represent sEs. (B) Monthly accumulated precipitation minus $\mathrm{ET}_{\mathrm{o}}(\mathrm{mm})$ in 2010 and 2011, Jay, FL. $\mathrm{ET}_{\mathrm{o}}=$ reference evapotranspiration

was arranged as a randomized split block design with four replications. After establishment, irrigation was applied twice weekly at a rate of $120 \%$ of reference $\mathrm{ET}_{\mathrm{o}}$ accumulated since the previous irrigation event. This was determined by the FAO Penman-Monteith equation available from a Florida Automated Weather Network (http://fawn.ifas.ufl.edu/) weather station located at the WFREC. Rain gauges were placed every $15.2 \mathrm{~m}$ parallel to the center and every $3.1 \mathrm{~m}$ perpendicular to the center irrigation line toward the outer edge to monitor and adjust the irrigation gradient. The distribution of irrigation on the LGIS is illustrated in Figure 2A. St. augustinegrass and $\mathrm{BH}$ were mowed weekly at $7.6 \mathrm{~cm}$ and $\mathrm{CP}$ was mowed at $5.0 \mathrm{~cm}$. Fertilizer was applied following University of Florida/Institute of Food and Agricultural Sciences Extension recommendations for lawn grasses grown in north Florida (Sartain, 2007) using LESCO $18 \mathrm{~N}-0 \mathrm{P}-18 \mathrm{~K}$ (Lesco, Inc., Cleveland, OH) and Agrium Super Rainbow 10N-10P-10K Plant Food (Agrium U.S. Inc., Denver, CO). Pesticide applications are listed in Table 1.

Data collection and analysis. From Sept. 2010 to July 2011, visual ratings were taken every 2 weeks for turf color, quality, and density. Visual ratings, following the National Turfgrass Evaluation Program Guidelines (Morris and Shearman, 2007), were recorded every $3.1 \mathrm{~m}$ from the center line toward the outer edge on each plot. A polynomial regression between irrigation level and the distance from central irrigation line was fitted to determine irrigation levels along the gradient (Fig. 2A), and the irrigation level was rounded up to the nearest tenth. In addition, chlorophyll index $(\mathrm{CI})$ readings were obtained using a FieldScout ${ }^{\circledR}$ CM1000 Chlorophyll Meter (Spectrum ${ }^{\circledR}$ Technologies, Inc., Plainfield, IL). Chlorophyll index reading ranges from 0 to 999 , and a higher value is correlated with higher quantity of chlorophyll in leaves. Periods of drought stress during the study were determined using available meteorological data (Fig. 2B) and visual symptoms of turfgrass leaf wilting or firing. The identified dates of drought stress were: 9 Sept. 2010; 22 Sept. 2010; 14 Oct. 2010; 29 Oct. 2010; 25 May 2011; 9 June 2011; 23 June 2011; and 10 July 2011. Data from the chosen dates were subjected to analysis of variance procedures to test the effects of different cultivars and irrigation levels using $\mathrm{SAS}^{\circledR}$ 9.2 (SAS Institute Inc., Cary, NC). Data from different rating dates were treated as repeated measures and significant main effects were separated using Tukey's honestly significant difference test. There was no interaction between cultivar and sampling date; therefore, data from rating dates were pooled and are presented together.

\section{Results and Discussion}

This study assessed turf performance and persistence of different cultivars under irrigation based on varying ET rates during naturally occurring drought periods in north Florida. These drought periods were generally less than 2 weeks before a 7- to $20-\mathrm{mm}$ precipitation event occurred except for one 4-week period without rain in Oct. 2010. Visual quality, color, and density were found to be different among the nine cultivars (Tables 2-5).

Both CP cultivars were consistently rated in the top statistical group at all irrigation rates for their overall quality and density compared with other cultivars (Tables 2 and 3). However, no difference was found in visual quality, color, and density or CI between 'Common' and 'TifBlair' (Tables $2-5)$. Centipedegrass is the most commonly used species for home lawns in the Florida Panhandle, and it is well adapted to acidic and infertile soils with good recovery after prolonged drought (Unruh et al., 2011). In this study, the low irrigation quantity needed to maintain acceptable quality and cover of CP cultivars compared with STA cultivars agrees with the high ranking of drought resistance and good recovery for 'TifBlair' $\mathrm{CP}$ reported in two previous studies (Huang et al., 1997a, 1997b). 'TifBlair' had superior canopy responses, which were attributed to great plasticity in rooting characteristics such as enhanced root growth at deeper soil profile and rapid root regrowth after rewatering (Huang et al., 1997b).

Bahiagrass and CP were generally rated higher in quality compared with st. augustinegrass cultivars (Table 2). 'Argentine' $\mathrm{BH}$ was reported to have $30 \%$ greater water use compared with 'Floratam' STA under non-limiting water conditions, and this 
characteristic contributed to its faster water depletion under a controlled drydown study, where shallow pots restricted the roots from exploring deeper soil moisture (Cathey et al., 2013). However, in the field, deep rooting characteristics of 'Argentine' allow it to delay its water deficit status during short drought periods (Wherley et al., 2011). This may explain why 'Argentine' had better quality when irrigation was less than $40 \% \mathrm{ET}_{\mathrm{o}}$, and its

Table 1. Applications of pesticides on the Linear Gradient Irrigation System (LGIS) in 2010 and 2011.

\begin{tabular}{llll}
\hline Application date & \multicolumn{1}{c}{ Chemical } & Function & Rate \\
\hline 19 Mar. 2010 & 2, 4-dichlorophenoxyacetic acid & Herbicide & $1.17 \mathrm{~L} \cdot \mathrm{ha}^{-1}$ \\
31 Aug. 2010 & Bifenthrin & Insecticide & $0.66 \mathrm{~L} \cdot \mathrm{ha}^{-1}$ \\
14 Oct. 2010 & Trifloxystrobin & Fungicide & $0.36 \mathrm{~kg} \cdot \mathrm{ha}^{-1}$ \\
27 Oct. 2011 & Prodiamine & Herbicide & $0.36 \mathrm{~kg} \cdot \mathrm{ha}^{-1}$ \\
2 Mar. 2011 & 2, 4-dichlorophenoxyacetic acid & Herbicide & $1.17 \mathrm{~L} \cdot \mathrm{ha}^{-1}$ \\
22 Mar. 2011 & Azoxystrobin & Fungicide & $1.22 \mathrm{~kg} \cdot \mathrm{ha}^{-1}$ \\
23 Mar. 2011 & Prodiamine & Herbicide & $0.46 \mathrm{~kg} \cdot \mathrm{ha}^{-1}$ \\
\hline
\end{tabular}

density decline under severe water deficit was less than STA cultivars (Tables 2 and 3). Although $120 \% \mathrm{ET}_{\mathrm{o}}$ irrigation did not decrease the quality of 'Argentine', $80 \% \mathrm{ET}_{\mathrm{o}}$ irrigation was sufficient to maintain acceptable quality during drought periods. When there was little supplemental irrigation $(6 \%$ to $10 \% \quad \mathrm{ET}_{\mathrm{o}}$ ), 'Argentine' maintained better quality than STA cultivars (Table 2). Visual quality of 'Argentine' was similar to $\mathrm{CP}$ except at $40 \% \mathrm{ET}_{\mathrm{o}}$, where 'Common' $\mathrm{CP}$ had better quality (Table 2). Kim and Beard (1988) proposed that CP's high canopy resistance, slow vertical leaf extension rate, and prostrate growth habit accounted for its low ET

Table 2. Visual quality of nine turfgrass cultivars under different irrigation regimes during drought periods in 2010 and 2011.

\begin{tabular}{|c|c|c|c|c|c|c|c|c|c|}
\hline \multirow[b]{2}{*}{ Cultivar } & \multirow[b]{2}{*}{ Species } & \multicolumn{8}{|c|}{ Percent reference evapotranspiration } \\
\hline & & 120 & 110 & 80 & 60 & 40 & 20 & 10 & 6 \\
\hline Captiva & STA & $5.1 \mathrm{cBC}$ & $5.9 \mathrm{bcdA}$ & $5.8 \mathrm{bcA}$ & $5.6 \mathrm{bAB}$ & $4.8 \mathrm{cdC}$ & $4.2 \mathrm{cdD}$ & $3.1 \mathrm{bE}$ & $2.6 \mathrm{bcF}$ \\
\hline Classic & STA & $5.4 \mathrm{bcBC}$ & $6.0 \mathrm{bcA}$ & $5.9 \mathrm{bcA}$ & $5.6 \mathrm{bAB}$ & $5.0 \mathrm{cC}$ & $4.4 \mathrm{bcD}$ & $3.3 \mathrm{bE}$ & $2.4 \mathrm{cF}$ \\
\hline Floratam & STA & $5.2 \mathrm{bcBC}$ & $5.7 \mathrm{cdA}$ & $5.6 \mathrm{cdAB}$ & $5.5 \mathrm{bAB}$ & $4.9 \mathrm{cC}$ & $4.1 \mathrm{cdD}$ & $3.2 \mathrm{bE}$ & $2.2 \mathrm{cdF}$ \\
\hline Palmetto & STA & $4.7 \mathrm{cdBC}$ & $5.4 \mathrm{dA}$ & $5.1 \mathrm{de} A B$ & $4.5 \mathrm{cC}$ & $3.4 \mathrm{eD}$ & $2.9 \mathrm{eD}$ & $1.9 \mathrm{cE}$ & $1.5 \mathrm{dE}$ \\
\hline Raleigh & STA & $5.3 \mathrm{bcBC}$ & $5.8 \mathrm{cdA}$ & $5.7 \mathrm{cdA}$ & $5.4 \mathrm{bAB}$ & $5.0 \mathrm{cC}$ & $4.0 \mathrm{cdD}$ & $3.0 \mathrm{bE}$ & $2.2 \mathrm{cdF}$ \\
\hline Mean & & $5.3 \mathrm{C}$ & $5.8 \mathrm{~A}$ & $5.8 \mathrm{~A}$ & $5.5 \mathrm{~B}$ & $5.0 \mathrm{D}$ & $4.3 \mathrm{E}$ & $3.4 \mathrm{~F}$ & $2.6 \mathrm{G}$ \\
\hline
\end{tabular}

${ }^{2} \mathrm{BH}=$ bahiagrass; $\mathrm{STA}=$ st. augustinegrass; $\mathrm{CP}=$ centipedegrass

${ }^{y}$ Visual ratings are based on a 1 to 9 scale following National Turfgrass Evaluation Program guidelines with the acceptable turf quality to be 6 .

${ }^{x}$ Means averaged across selected dates in 2010 and 2011 in the columns followed by the same lowercase letter are not different at the $0.05 P$ level.

wMeans averaged across selected dates in 2010 and 2011 in the rows followed by the same uppercase letter are not different at the $0.05 P$ level.

Table 3. Visual density of nine turfgrass cultivars under different irrigation regimes during drought periods in 2010 and 2011.

\begin{tabular}{|c|c|c|c|c|c|c|c|c|c|}
\hline \multirow[b]{2}{*}{ Cultivar } & \multirow[b]{2}{*}{ Species } & \multicolumn{8}{|c|}{ Percent reference evapotranspiration } \\
\hline & & 120 & 110 & 80 & 60 & 40 & 20 & 10 & 6 \\
\hline Argentine & $\mathrm{BH}^{2}$ & $6.4^{\mathrm{y}} \mathrm{ab}^{\mathrm{x}} \mathrm{A}^{\mathrm{w}}$ & $6.3 \mathrm{bcA}$ & $6.2 \mathrm{bcdA}$ & $6.0 \mathrm{bcA}$ & $5.8 \mathrm{cdB}$ & $5.4 \mathrm{bcC}$ & $4.8 \mathrm{abD}$ & $4.3 \mathrm{abE}$ \\
\hline Captiva & STA & $6.4 \mathrm{abBC}$ & $7.2 \mathrm{aA}$ & $7.0 \mathrm{abA}$ & $6.8 \mathrm{abAB}$ & $5.9 \mathrm{cdCD}$ & $5.5 \mathrm{bcD}$ & $4.4 \mathrm{bcE}$ & $3.9 \mathrm{abcF}$ \\
\hline Common & $\mathrm{CP}$ & $7.0 \mathrm{aB}$ & $7.3 \mathrm{aA}$ & $7.4 \mathrm{aAB}$ & $7.2 \mathrm{aAB}$ & $7.1 \mathrm{aAB}$ & $6.4 \mathrm{aC}$ & $5.5 \mathrm{aD}$ & $4.7 \mathrm{aE}$ \\
\hline Floratam & STA & $6.5 \mathrm{abAB}$ & $6.9 \mathrm{abA}$ & $6.9 \mathrm{abcA}$ & $6.7 \mathrm{abA}$ & $6.1 \mathrm{bcB}$ & $5.4 \mathrm{bcC}$ & $4.5 \mathrm{bcD}$ & $3.3 \mathrm{bcdE}$ \\
\hline Palmetto & STA & $5.8 \mathrm{bcBC}$ & $6.4 \mathrm{bA}$ & $6.1 \mathrm{cdAB}$ & $5.5 \mathrm{cC}$ & $4.6 \mathrm{eD}$ & $4.0 \mathrm{dE}$ & $2.7 \mathrm{dF}$ & $2.0 \mathrm{eG}$ \\
\hline Raleigh & STA & $6.3 \mathrm{abBC}$ & $6.8 \mathrm{abA}$ & 6.7 abcdAB & $6.5 \mathrm{abAB}$ & $6.0 \mathrm{bcdC}$ & $5.3 \mathrm{bcD}$ & $4.4 \mathrm{bcE}$ & $3.3 \mathrm{cdF}$ \\
\hline Mean & & $6.4 \mathrm{~B}$ & $6.8 \mathrm{~A}$ & $6.7 \mathrm{~A}$ & $6.5 \mathrm{~B}$ & $6.0 \mathrm{C}$ & $5.4 \mathrm{D}$ & $4.5 \mathrm{E}$ & $3.6 \mathrm{~F}$ \\
\hline
\end{tabular}

${ }^{ } \mathrm{BH}=$ bahiagrass; $\mathrm{STA}=$ st. augustinegrass; $\mathrm{CP}=$ centipedegrass.

${ }^{y}$ Visual ratings are based on a 1 to 9 scale following National Turfgrass Evaluation Program guidelines with the acceptable turf quality to be 6 .

${ }^{\times}$Means averaged across selected dates in 2010 and 2011 in the columns followed by the same lowercase letter are not different at the $0.05 P$ level.

"Means averaged across selected dates in 2010 and 2011 in the rows followed by the same uppercase letter are not different at the $0.05 P$ level.

Table 4. Visual color of nine turfgrass cultivars under different irrigation regimes during drought periods in 2010 and 2011.

\begin{tabular}{|c|c|c|c|c|c|c|c|c|c|}
\hline \multirow[b]{2}{*}{ Cultivar } & \multirow[b]{2}{*}{ Species } & \multicolumn{8}{|c|}{ Percent reference evapotranspiration } \\
\hline & & 120 & 110 & 80 & 60 & 40 & 20 & 10 & 6 \\
\hline Captiva & STA & $5.7 \mathrm{abAB}$ & $6.0 \mathrm{abA}$ & $5.8 \mathrm{abAB}$ & $5.7 \mathrm{abAB}$ & $5.3 \mathrm{aB}$ & $4.5 \mathrm{abcC}$ & $3.6 \mathrm{abD}$ & $3.1 \mathrm{abcE}$ \\
\hline Common & $\mathrm{CP}$ & $5.5 \mathrm{bA}$ & $5.8 \mathrm{abA}$ & $5.8 \mathrm{abA}$ & $5.6 \mathrm{abA}$ & $5.5 \mathrm{aA}$ & $4.8 \mathrm{abB}$ & $4.0 \mathrm{aC}$ & $3.3 \mathrm{abD}$ \\
\hline Floratam & STA & $5.3 \mathrm{bcAB}$ & $5.5 \mathrm{abcA}$ & $5.4 \mathrm{abA}$ & $5.3 \mathrm{abcAB}$ & $4.9 \mathrm{abB}$ & $4.3 \mathrm{abcC}$ & $3.2 \mathrm{bD}$ & $2.5 \mathrm{cdE}$ \\
\hline Palmetto & STA & $4.7 \mathrm{cdA}$ & $5.1 \mathrm{cdA}$ & $4.8 \mathrm{cdA}$ & $4.5 \mathrm{dA}$ & $4.0 \mathrm{cB}$ & $3.3 \mathrm{dC}$ & $2.2 \mathrm{cD}$ & $1.7 \mathrm{eE}$ \\
\hline Raleigh & STA & $5.1 \mathrm{bcdAB}$ & $5.4 \mathrm{bcA}$ & $5.3 \mathrm{bcA}$ & $5.1 \mathrm{bcdAB}$ & $4.8 \mathrm{abB}$ & $4.1 \mathrm{bcdC}$ & $3.1 \mathrm{bD}$ & $2.5 \mathrm{cdE}$ \\
\hline Mean & & $5.3 \mathrm{~B}$ & $5.5 \mathrm{~A}$ & $5.5 \mathrm{~A}$ & $5.3 \mathrm{~B}$ & $4.9 \mathrm{C}$ & $4.3 \mathrm{D}$ & $3.4 \mathrm{E}$ & $2.8 \mathrm{~F}$ \\
\hline
\end{tabular}

${ }^{2} \mathrm{BH}=$ bahiagrass; $\mathrm{STA}=$ st. augustinegrass; $\mathrm{CP}=$ centipedegrass.

${ }^{y}$ Visual ratings are based on a 1 to 9 scale following National Turfgrass Evaluation Program guidelines with the acceptable turf quality to be 6 .

${ }^{x}$ Means averaged across selected dates in 2010 and 2011 in the columns followed by the same lowercase letter are not different at the $0.05 P$ level.

"Means averaged across selected dates in 2010 and 2011 in the rows followed by the same uppercase letter are not different at the $0.05 P$ level. 
Table 5. Chlorophyll index of nine turfgrass cultivars under different irrigation regimes during drought periods in 2010 and 2011

\begin{tabular}{|c|c|c|c|c|c|c|c|c|c|}
\hline \multirow[b]{2}{*}{ Cultivar } & \multirow[b]{2}{*}{ Species } & \multicolumn{8}{|c|}{ Percent reference evapotranspiration } \\
\hline & & 120 & 110 & 80 & 60 & 40 & 20 & 10 & 6 \\
\hline Argentine & $\mathrm{BH}^{\mathrm{z}}$ & $265.8^{\mathrm{y}} \mathrm{a}^{\mathrm{x}} \mathrm{A}^{\mathrm{w}}$ & $251.8 \mathrm{aAB}$ & $243.0 \mathrm{abAB}$ & $233.2 \mathrm{aBC}$ & $213.8 \mathrm{aCD}$ & $199.7 \mathrm{aD}$ & $169.5 \mathrm{aE}$ & $155.1 \mathrm{aE}$ \\
\hline Captiva & STA & $241.1 \mathrm{abA}$ & $248.9 \mathrm{aA}$ & $247.7 \mathrm{aA}$ & $230.6 \mathrm{aA}$ & $205.9 \mathrm{abB}$ & $178.8 \mathrm{abC}$ & $145.6 \mathrm{bcD}$ & $135.7 \mathrm{abD}$ \\
\hline Classic & STA & $230.5 \mathrm{abcA}$ & $238.7 \mathrm{aA}$ & $238.6 \mathrm{abA}$ & $224.8 \mathrm{aA}$ & $217.0 \mathrm{aA}$ & $183.6 \mathrm{abB}$ & $147.2 \mathrm{bcC}$ & $125.0 \mathrm{bcD}$ \\
\hline Common & $\mathrm{CP}$ & 220.4 bcdAB & $231.3 \mathrm{aAB}$ & $240.8 \mathrm{abA}$ & $222.6 \mathrm{aAB}$ & $211.5 \mathrm{aB}$ & $188.1 \mathrm{abC}$ & $162.2 \mathrm{abD}$ & $136.1 \mathrm{abE}$ \\
\hline Floratam & STA & $223.1 \mathrm{bcdA}$ & $221.3 \mathrm{abA}$ & $219.5 \mathrm{abcA}$ & $214.1 \mathrm{aA}$ & $189.1 \mathrm{abB}$ & $177.2 \mathrm{abB}$ & $134.6 \mathrm{cdC}$ & $116.5 \mathrm{bcD}$ \\
\hline Palmetto & STA & $195.4 \mathrm{cdBC}$ & $221.5 \mathrm{abA}$ & $207.8 \mathrm{bcAB}$ & $195.3 \mathrm{aBC}$ & $170.5 \mathrm{bCD}$ & $154.9 \mathrm{bD}$ & $121.1 \mathrm{dE}$ & $103.4 \mathrm{cE}$ \\
\hline Raleigh & STA & $202.7 \mathrm{bcdB}$ & $225.2 \mathrm{abA}$ & $212.2 \mathrm{abcAB}$ & $211.7 \mathrm{aAB}$ & $193.9 \mathrm{abB}$ & $170.2 \mathrm{abC}$ & $140.2 \mathrm{cdD}$ & $119.0 \mathrm{bcE}$ \\
\hline Sapphire & STA & $182.4 \mathrm{dAB}$ & $198.5 \mathrm{bA}$ & $189.1 \mathrm{cA}$ & $193.1 \mathrm{aA}$ & $168.5 \mathrm{bBC}$ & $160.3 \mathrm{bC}$ & $135.5 \mathrm{cdD}$ & $117.0 \mathrm{bcE}$ \\
\hline TifBlair & $\mathrm{CP}$ & $201.2 \mathrm{bcdBC}$ & $219.7 \mathrm{abA}$ & $221.2 \mathrm{abcA}$ & $219.1 \mathrm{aAB}$ & $202.5 \mathrm{abAB}$ & $183.9 \mathrm{abC}$ & $162.8 \mathrm{abD}$ & $134.8 \mathrm{abE}$ \\
\hline Mean & & $217.8 \mathrm{BC}$ & $228.2 \mathrm{~A}$ & $224.3 \mathrm{AB}$ & $216.2 \mathrm{C}$ & $197.3 \mathrm{D}$ & $177.7 \mathrm{E}$ & $147.0 \mathrm{~F}$ & $127.8 \mathrm{G}$ \\
\hline
\end{tabular}

${ }^{\mathrm{z}} \mathrm{BH}=$ bahiagrass; STA $=$ st. augustinegrass; $\mathrm{CP}=$ centipedegrass.

${ }^{\mathrm{y}} \mathrm{Chlorophyll}$ index is calculated based on the light reflectance at 700 and $840 \mathrm{~nm}$, which is used to estimate the quantity of leaf chlorophyll.

${ }^{x}$ Means averaged across selected dates in 2010 and 2011 in the columns followed by the same lowercase letter are not different at the $0.05 P$ level.

${ }^{w}$ Means averaged across selected dates in 2010 and 2011 in the rows followed by the same uppercase letter are not different at the $0.05 P$ level.

rate under non-limiting water conditions. This characteristic may benefit $\mathrm{CP}$ to use the soil moisture slower compared with $\mathrm{BH}$, resulting in differences in turfgrass quality between $\mathrm{BH}$ and $\mathrm{CP}$ during moderate water deficits (i.e., $40 \%$ to $60 \% \mathrm{ET}_{\mathrm{o}}$ ). As the irrigation level continued to decrease (less than $40 \% \mathrm{ET}_{\mathrm{o}}$ ), $\mathrm{CP}$ and $\mathrm{BH}$ were not visually different (Table 2).

Comparing the effect of irrigation level on each cultivar, in general, visual quality decreased under irrigation level of $120 \% \mathrm{ET}_{\mathrm{o}}$ compared with that $110 \%$ and $80 \% \mathrm{ET}_{\mathrm{o}}$ (Table 2). 'Argentine' was an exception with similar visual quality under irrigation levels ranging from $80 \%$ to $120 \% \mathrm{ET}_{\mathrm{o}}$. This does not necessarily suggest that 'Argentine' is less affected by overirrigation. As a result of its high ET rate (high crop coefficient) (Jia et al., 2009), the irrigation level of $120 \% \mathrm{ET}_{\mathrm{o}}$ may not exert any negative impacts. Jia et al. (2009) reported that on an annual basis, the crop coefficients of $\mathrm{BH}$ were found to be the highest in April and May in central Florida as a result of high vapor pressure deficits. Whether the increase of the crop coefficient of $\mathrm{BH}$ during periodic drought is greater than other turf species needs further exploration.

Variations were found among the six STA cultivars (Tables 2-4). 'Palmetto' was rated lower in quality compared with 'Captiva', 'Classic', 'Floratam', and 'Raleigh' except at higher irrigation levels $\left(80 \% \mathrm{ET}_{\mathrm{o}}\right.$ or greater $)$. The performance of 'Palmetto' in this study was similar to Steinke et al. (2010) in which 'Palmetto' lost $50 \%$ green cover $10 \mathrm{~d}$ earlier than 'Floratam' under field drydown combined with high air temperature. With these dramatic differences, cultivar selection could make a significant difference in water conservation by reducing the need for supplemental irrigation and better use of natural precipitation. 'Captiva', 'Classic', 'Floratam', and 'Raleigh' had similar visual quality overall irrigation regimes and were not different from 'Argentine' $\mathrm{BH}$ at the $40 \%$ to $110 \% \mathrm{ET}_{\mathrm{o}}$ irrigation level. 'Sapphire' had the lowest visual quality and density at high irrigation levels $\left(110 \% \mathrm{ET}_{\mathrm{o}}\right.$ or greater) compared with other cultivars, but it performed similar to 'Palmetto' at moderate water deficits $\left(40 \%\right.$ to $\left.80 \% \mathrm{ET}_{\mathrm{o}}\right)$. At severe water deficits (less than 20\% ET o $_{\mathrm{o}}$ ), 'Sapphire' had better quality compared with 'Palmetto' and similar quality ratings with other STA cultivars. Previous studies provide little evidence demonstrating that 'Sapphire' has better drought tolerance than other STA cultivars. 'Sapphire' was reported to have inconsistent performance over 2 years (Steinke et al., 2010). Moreover, results from our study suggest that STA cultivars (except for 'Palmetto' and 'Sapphire') performed similar to 'Argentine' BH during periodic droughts of less than 2 weeks in duration if some supplemental irrigation $\left(40 \% \mathrm{ET}_{\mathrm{o}}\right.$ or greater) is provided.

Visual color, density, and CI values are comparable with visual quality (Tables 3-5). 'Argentine' BH had the highest color rating at $120 \% \mathrm{ET}_{\mathrm{o}}$ (Table 4). Color ratings were similar for 'Argentine', 'Captiva', 'Classic', 'Floratam', 'Common', and 'TifBlair' when irrigation levels were $60 \%$ to $110 \% \mathrm{ET}_{\mathrm{o}}$. 'Palmetto', 'Raleigh', and 'Sapphire' had lower color than other cultivars. Comparisons of color ratings agreed with CI values between $\mathrm{BH}$ and $\mathrm{CP}$ (Tables 4 and 5). There was little separation in CI values at $20 \%$ to $110 \% \mathrm{ET}_{\mathrm{o}}$ except for 'Palmetto' and 'Sapphire' having lower CI values (Table $5)$. Under severe water deficit $\left(10 \% \mathrm{ET}_{\mathrm{o}}\right.$ or less), 'Argentine' had higher CI than STA cultivars and similar values to $\mathrm{CP}$.

Results in visual color, density, and CI affected by irrigation level suggested that the best turf performance was achieved when irrigation was between $60 \%$ and $110 \% \mathrm{ET}_{\mathrm{o}}$ (Tables 3-5). Thus, considerable latitude exists for water conservation by adjusting the irrigation accordingly. A previous study demonstrated that a rapid decline of turf quality in kentucky bluegrass (Poa pratensis L.), tall fescue (Festuca arundinacea Schreb.), and buffalograss [Buchloe dactyloides (Nutt.) Engem.] did not occur until the irrigation level dropped to $70 \%$ of actual ET $\left(\mathrm{ET}_{\mathrm{a}}\right)$ (Feldhake et al., 1984). This agrees with our study ( $60 \%$ to $80 \% \mathrm{ET}_{\mathrm{o}}$ ), assuming the crop coefficient to be $\approx 0.8$. Other studies recommended $60 \%$ to $80 \% \mathrm{ET}_{\mathrm{a}}$ to maintain acceptable quality in bentgrass (Agrostis spp.), tall fescue, bermudagrass [Cynodon dactylon (L.) Pers. $\times$ C. transvaalensis Burtt-Davy], and zoysiagrass (Zoysia japonica Steud.) (DaCosta and Huang, 2006; Fu et al., 2004). In regions where periods of drought are typically short term, turf irrigation recommendations could be adjusted downward.

This study demonstrated that drought stress can occur on BH, CP, and STA when ET exceeds natural precipitation and supplemental irrigation for an extended period. Additionally, as ET replacement decreases, cultivar responses were found to vary under different levels of drought stress. The results suggest that $\mathrm{CP}\left(40 \% \mathrm{ET}_{\mathrm{o}}\right)$ and $\mathrm{BH}(60 \%$ $\mathrm{ET}_{\mathrm{o}}$ ) generally required less supplemental irrigation to maintain acceptable quality during periodic drought compared with STA $\left(60 \%\right.$ to $\left.80 \% \mathrm{ET}_{\mathrm{o}}\right)$. Among STA cultivars, 'Palmetto' performed poorest in its relative drought response than other cultivars. 'Sapphire' needs further study to better characterize its drought response. The irrigation replacement at $120 \% \mathrm{ET}_{\mathrm{o}}$ generally decreased turf quality, and $40 \%$ to $80 \% \mathrm{ET}_{\mathrm{o}}$, depending on turfgrass species and cultivars, may provide enough supplemental moisture to maintain turf quality during short-duration drought $(\approx 2$ weeks $)$.

\section{Literature Cited}

Bañuelos, J.B., J.L. Walworth, P.W. Brown, and D.M. Kopec. 2011. Deficit irrigation of seashore paspalum and bermudagrass. Agron. J. 103:1567-1577.

Carrow, R.N. 1995. Drought resistance aspects of turfgrasses in the southeast-Evapotranspiration and crop coefficients. Crop Sci. 35:1685-1690.

Carrow, R.N. 1996. Drought resistance aspects of turfgrasses in the southeast: Root-shoot responses. Crop Sci. 36:687-694.

Cathey, S.E., J.K. Kruse, T.R. Sinclair, and M.D. Dukes. 2013. Transpiration and visual appearance of warm season turfgrasses during soil drying. Environ. Exp. Bot. 89:36-43.

DaCosta, M. and B. Huang. 2006. Deficit irrigation effects on water use characteristics of bentgrass species. Crop Sci. 46:1779-1786.

Feldhake, C.M., R.E. Danielson, and J.D. Butler 1984. Turfgrass evapotranspiration. 11. Responses to deficit irrigation. Agron. J. 76:85-89.

Fu, J.M., J. Fry, and B.R. Huang. 2004. Minimum water requirements of four turfgrasses in the transition zone. HortScience 39:1740-1744.

Huang, B., R.R. Duncan, and R.N. Carrow. 1997a. Drought-resistance mechanisms of seven warmseason turfgrasses under surface soil drying.1. Shoot response. Crop Sci. 37:1858-1863. 
Huang, B., R.R. Duncan, and R.N. Carrow. 1997b. Drought-resistance mechanisms of seven warm-season turfgrasses under surface soil drying. 2. Root aspects. Crop Sci. 37:1863-1869.

Jia, X., M.D. Dukes, and J.M. Jacobs. 2009. Bahiagrass crop coefficients from eddy correlation measurements in central Florida. Irrig. Sci. 28:5-15.

Kim, K.S. and J.B. Beard. 1988. Comparative turfgrass evapotranspiration rates and associated plant morphological characteristics. Crop Sci. 28:328-331.

Morris, K.N. and R.C. Shearman. 2007. NTEP turfgrass evaluation guidelines. National Turfgrass Evaluation Program, Beltsville, MD.

Qian, Y.L. and M.C. Engelke. 1999. Performance of five turfgrasses under linear gradient irrigation. HortScience 34:893-896.
Sartain, J.B. 2007. General recommendations for fertilization of turfgrass on Florida soils. University of Florida/IFAS Extension. 5 Feb. 2015. <https://edis.ifas.ufl.edu/pdffiles/LH/ LH01400.pdf>.

Satterthwaite, L.N., A.W. Hodges, J.J. Haydu, and J.L. Cisar. 2009. An agronomic and economic profile of Florida's sod industry in 2007. Univ. of Florida, IFAS, Florida Agric. Exp. Stn., Florida Coop. Ext. Serv., Gainesville, FL.

Steinke, K., D. Chalmers, J. Thomas, R. White, and G. Fipps. 2010. Drought response and recovery characteristics of St. Augustinegrass cultivars. Crop Sci. 50:2076-2083.

Trenholm, L.E., J.L. Cisar, and J.B. Unruh. 2011a. Bahiagrass for Florida lawns. University of Florida/IFAS Extension. 5 Feb. 2015. <https:// edis.ifas.ufl.edu/pdffiles/LH/LH00600.pdf>.
Trenholm, L.E., J.L. Cisar, and J.B. Unruh. 2011b. St. Augustinegrass for Florida lawns. University of Florida/IFAS Extension. 5 Feb. 2015 $<$ https://edis.ifas.ufl.edu/pdffiles/LH/LH01000. pdf $>$.

Unruh, J.B., L.E. Trenholm, and J.L. Cisar. 2011. Centipedegrass for Florida lawns. University of Florida/IFAS Extension. 5 Feb. 2015. <https:// edis.ifas.ufl.edu/pdffiles/LH/LH00900.pdf>.

Wherley, B.G., T.R. Sinclair, M.D. Dukes, and A.K. Schreffler. 2011. Nitrogen and cutting height influence root development during warmseason turfgrass sod establishment. Agron. J. 103:1629-1634.

Zhang, J., J.B. Unruh, and K. Kenworthy. 2013. Zoysiagrass cultivar responses under a linear gradient irrigation system. Intl. Turfgrass Soc. Res. J. 12:179-186. 